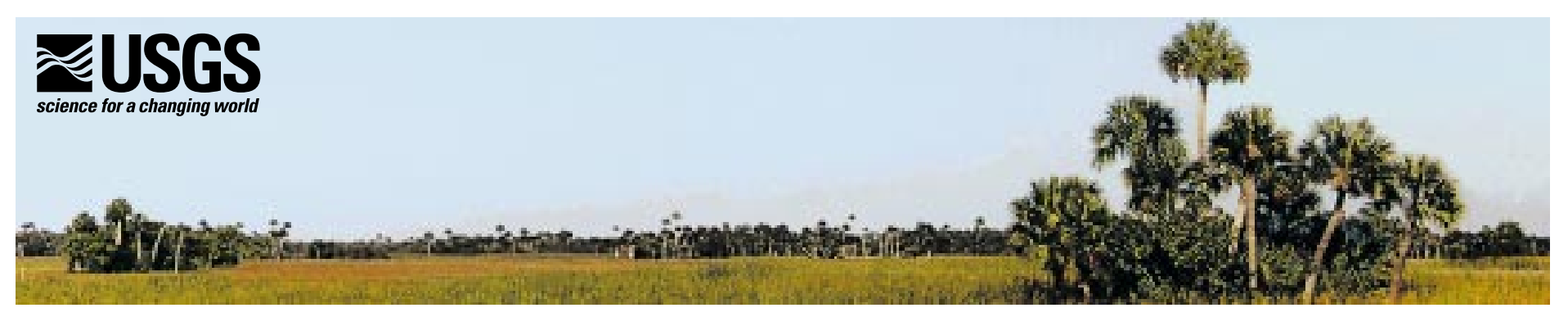

National Water-Quality Assessment Program

\title{
Water-Quality Assessment of Southern Florida- Wastewater Discharges and Runoff
}

Nearly 800 million gallons per day of treated wastewater was discharged in the Southern Florida National Water-Quality Assessment (NAWQA) study unit in 1990, most to the Atlantic Ocean (44 percent) and to deep, saline aquifers (25 percent). About 9 percent was discharged to fresh surface waters and about 22 percent to shallow ground water, of which septic tanks accounted for 9 percent. Runoff from agricultural and urban lands, though not directly measured, is a large source of wastewater in southern Florida.

\section{INTRODUCTION}

Population growth and activities in the south Florida area over the past 40 years have resulted in increased water use, changes in the distribution and timing of flow, and deterioration of water quality. These changes threaten both the remaining natural ecosystem and the growing human population. Wetlands and shallow waters in the region are sensitive to increased nutrient and contaminant inputs that are often associated with wastewater discharges and stormwater runoff. Discharges and runoff reaching the coast through canals can adversely affect south Florida's estuaries and bays. The Biscayne aquifer in southeastern Florida, the sole source of drinking water for nearly 3.4 million people, is at risk of contamination because of its shallow depth, highporosity, and location beneath an area of intense urbanization.

Recent consensus has been reached among Federal and State agencies and environmental groups that the south Florida ecosystem, and the Everglades in particular, should be protected and restored, to the extent possible, to its predevelopment condition. Protection and restoration will require a thorough understanding of the distribution, amount, and quality of water in the area and the human and natural processes that affect the water. The U.S. Geological Survey is providing scientific information that will contribute to the protection and restoration effort through such programs as NAWQA and the South Florida Ecosystem Initiative.

This report provides information on sources of wastewater discharge and runoff within the Southern Florida (SOFL) NAWQA study area (fig. 1). This information can be used in evaluating the potential effects of wastewater on water quality of the region.

\section{SOUTHERN FLORIDA NAWQA STUDY UNIT}

The Southern Florida NAWQA study unit encompasses an area of about 19,500 square miles in southern and central Florida (fig. 1). Within the study unit are areas of agricultural and urban development, phosphate mining, islands (keys), and wetlands (marshes and swamps). Agriculture is widespread, but it is most intensive in the Everglades Agricultural Area (EAA), south of Lake

Okeechobee, and in western Dade County. Nearly 5.8 million people resided in the study unit in 1990, in addition to several million visitors and seasonal residents. Most people live near the coast of the Atlantic Ocean and the Gulf of Mexico where the population has increased 100 percent in the 20 years from 1970 and 1990. Phosphate mining is predominantly in the

Peace River Basin mostly in DeSoto, Hardee, and Manatee Counties. Wetlands cover
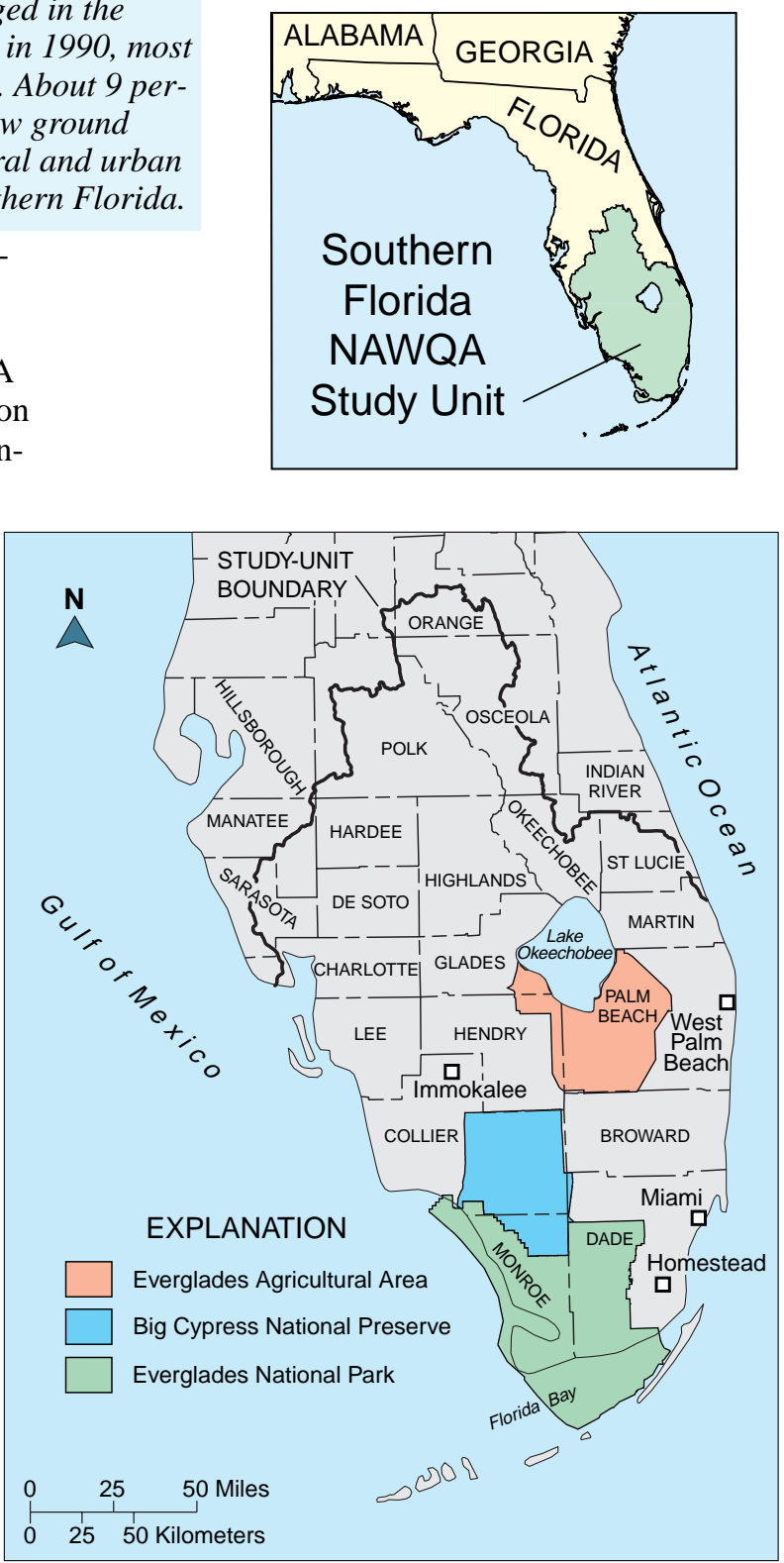

Figure 1. The Southern Florida NAWQA study unit.

large areas including much of Everglades National Park, Big Cypress National Preserve, and several water conservation areas and other public lands. 


\section{WASTEWATER}

Wastewater is generated from human activities. It includes (1) discharge from domestic (municipal) and industrial treatment plants and septic tanks, and (2) runoff from agricultural lands, urban areas, and landfills. The water from wastewater facilities is treated before release, and then it is discharged to streams, shallow boreholes, or deeper injection wells. In 1990, treated wastewater discharged from domestic and industrial facilities and septic tanks in the study unit totaled more than 787 million gallons per day (Mgal/d) (Marella, 1994). Nearly $413 \mathrm{Mgal} / \mathrm{d}$, or 53 percent of the treated wastewater, was discharged to surface-water bodies (fig. 2) with more than three-quarters of this total ( $344 \mathrm{Mgal} / \mathrm{d})$ being discharged to the Atlantic Ocean. The remaining 47 percent of the treated wastewater was discharged to the subsurface, with more than two-thirds (196 Mgal/d) being discharged into deep nonpotable aquifers through injection wells (fig. 2). Although the discharged wastewater is regulated in both quantity and quality, it can adversely affect water quality of the receiving water bodies, particularly if they have restricted circulation or a limited capacity for dilution. In the Florida Keys, for example, there is concern that wastewater from some 240 small package treatment plants seeping from shallow injection wells into marine waters may be adversely affecting the very sensitive coral reefs and other near-shore communities (Shinn and others, 1994).

Agricultural and urban runoff are major nonpoint sources of nutrients and contaminants to southern Florida waters. Because runoff is from nonpoint sources, it is difficult to quantify; instead, for this study the areal extent of agricultural and urban land uses was used as an indicator of the effect of runoff on southern Florida. The nutrients and contaminants come from fertilizers, pesticides, manure, and urban waste. Fertilizer and manure dominate nutrient inputs to the southern Florida basins; wastewater treatment plant inputs are insignificant in comparison (Haag and others, 1996). In the northern Everglades, agricultural runoff of nutrients has resulted in overenrichment and ecological disruption of wetlands, and there is concern that these adverse effects will become visible in the southern Everglades, including the Everglades National Park (McPherson and Halley, 1997). Long-term data already show that changes in water quality in the southern
WASTEWATER DISCHARGES

[Totaled more than 787 million gallons per day in 1990, \%, percent]

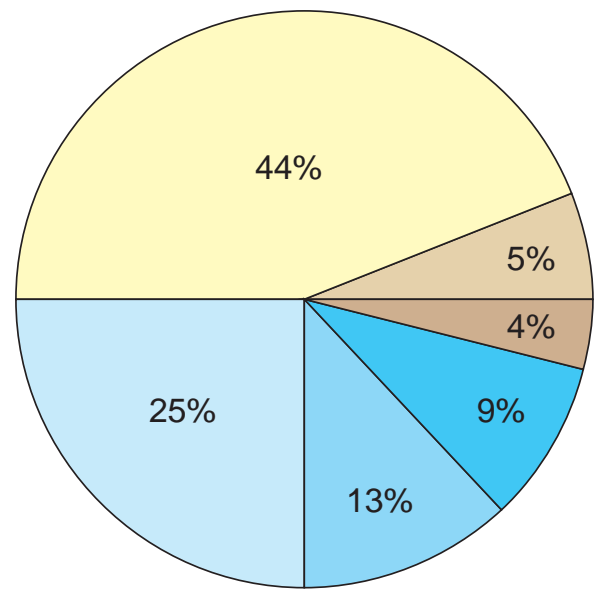

TO SURFACE WATER

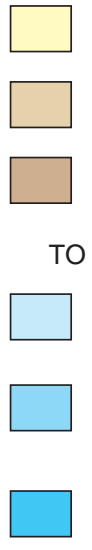

Domestic discharge to saline water

Domestic discharge to freshwater

Industrial discharge to freshwater

TO SUBSURFACE/GROUND WATER

Domestic discharge to injection wells or boreholes

Domestic discharge to drain field, percolation ponds, spray fields, and reuse systems

Septic tank discharge to drain
fields

Figure 2. Wastewater discharged by source and destination in the southern Florida study unit, 1990.

Everglades have occurred; specific conductance and major ion concentrations have increased in the Shark River Slough (Flora and Rosendahl, 1982). Continued residential development along the southeastern coast and the Florida Keys also will intensify problems in coastal waters as a result of increased stormwater runoff, septic tank and disposal well leachate, and inputs of nutrients and heavy metals from marinas and live-aboard vessels. Landfills are also a water-quality concern, as contaminants can leach into the ground and surface waters and adversely affect local water quality.

\section{Domestic Wastewater Discharges}

An estimated 1,500 domestic wastewater facilities within the SOFL study unit were regulated by the Florida Department of Environmental Protection (FDEP) in 1990. These facilities receive or dispose of wastewater derived principally from residential dwellings, business, or commercial buildings, institutions, and some industrial facilities (Marella, 1994). Data were collected for the 350 facilities that had a capacity of greater than $0.01 \mathrm{Mgal} / \mathrm{d}$. Discharge from these 350 facilities, which served 72 percent of the population (4.2 million), accounted for nearly 99 percent of the treated domestic wastewater discharged during 1990. Discharge from the remaining 1,150 smaller facilities totaled about $10 \mathrm{Mgal} / \mathrm{d}$ (estimated by assuming a maximum discharge of $0.009 \mathrm{Mgal} / \mathrm{d}$ per system). These smaller domestic wastewater facilities, together with septic tanks, served the remaining 28 percent of the population (1.6 million).

Discharge of treated wastewater from the domestic wastewater facilities in 1990 totaled $682 \mathrm{Mgal} / \mathrm{d}$, of which approximately 57 percent (390 Mgal/d)

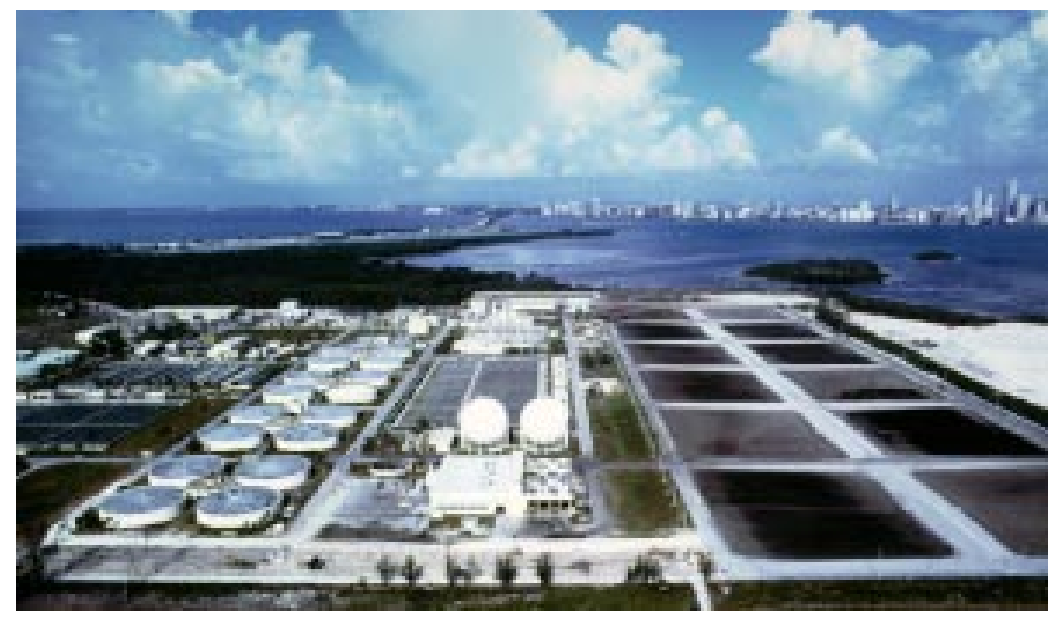

Domestic wastewater facility, Dade County. (Photo courtesy of the Florida Department of Environmental Protection.) 
Table 1. Wastewater discharged by county in Southern Florida NAWQA study unit, 1990

[Values in million gallons per day. Modified from Marella, 1994]

\begin{tabular}{lcccc}
\hline & Domestic & Industrial & $\begin{array}{c}\text { Septic } \\
\text { tanks }\end{array}$ & $\begin{array}{c}\text { Total } \\
\text { discharged }\end{array}$ \\
\hline Broward & 171.02 & 0 & 7.80 & 178.82 \\
Charlotte* & 4.75 & 0 & 3.75 & 8.50 \\
Collier & 16.41 & 0 & 2.61 & 19.02 \\
Dade & 283.36 & 0 & 15.73 & 299.09 \\
DeSoto & 1.10 & 0 & 0.87 & 1.97 \\
Glades & 0.05 & 0 & 0.56 & 0.61 \\
Hardee & 1.11 & 0 & 0.60 & 1.71 \\
Hendry & 2.14 & 8.55 & 0.71 & 11.40 \\
Highlands & 2.44 & 0 & 3.03 & 5.47 \\
Hillsborough* & 0 & 0 & 0 & 0 \\
Lee & 29.11 & 0 & 7.35 & 36.46 \\
Manatee* & 0 & 0 & 0.16 & 0.16 \\
Martin* & 4.49 & 0.27 & 2.98 & 7.74 \\
Monroe & 9.45 & 0 & 2.97 & 12.42 \\
Okeechobee* & 0.38 & 0 & 1.40 & 1.78 \\
Orange* & 34.05 & 0 & 1.89 & 35.94 \\
Osceola* & 10.22 & 0 & 1.86 & 12.08 \\
Palm Beach & 84.29 & 1.18 & 6.84 & 92.31 \\
Polk* & 24.30 & 21.96 & 8.12 & 54.38 \\
St. Lucie* & 2.50 & 0 & 3.19 & 5.69 \\
Sarasota* & 1.45 & 0 & 0.55 & 2.00 \\
\multicolumn{1}{c}{ Totals } & 682.22 & 31.96 & 72.97 & 787.15 \\
\hline * Only part of county is within the study unit & & &
\end{tabular}

* Only part of county is within the study unit.

was discharged to surface water and 43 percent $(292 \mathrm{Mgal} / \mathrm{d})$ to ground water. The Atlantic Ocean received 88 percent of the surface-water discharges; deep nonpotable aquifers received 67 percent of the ground-water discharge through injection wells. Land application systems (drain fields, percolation ponds, spray fields, shallow wells, and reuse irrigation systems) accounted for the remaining wastewater released to the ground. Broward and Dade Counties accounted for twothirds (454 Mgal/d) of the study unit's domestic discharge in 1990 (table 1). Within these study areas, 41 domestic wastewater facilities discharged more than $1 \mathrm{Mgal} / \mathrm{d}$ each (fig. 3), totaling 80 percent of the discharge produced in 1990.

\section{Industrial Wastewater Discharges}

According to the FDEP, industrial wastewater facilities are those that produce, treat, or dispose of wastewater not otherwise defined primarily as domestic wastewater, including the runoff and leachate from areas that receive contaminants associated with industrial or commercial storage, handling, or processing (Marella, 1994). Nearly all of the 18 facilities in the study area have a capacity of more than $0.04 \mathrm{Mgal} / \mathrm{d}$, but often discharge well below their capacities, discharge only seasonally, or do not discharge at all during a given year. This is particularly true for food processing plants and mining operations within the study unit, as many of these facilities only operate seasonally. Discharge of treated wastewater from the 18 industrial wastewater facilities totaled nearly $32 \mathrm{Mgal} / \mathrm{d}$ in 1990. Additionally, an undetermined amount of untreated water was discharged from mining operations (from dewatering or stormwater retention). Nearly all (99.9 percent) of the industrial wastewater was discharged to surface water. Most of the industrial operations within the study unit dispose of their wastewater through domestic facilities (municipal sewer). As regulations increase regarding the quality and quantity of wastewater discharges allowed in Florida, it has become more cost effective for industrial water users to discharge their wastewater to domestic facilities for treatment and disposal, rather than treating it themselves. Additionally, industrial users recycle more water than in the past. As a result, discharge of industrial wastewater in southern Florida decreased about 33 percent from 1985 to 1990.

\section{Wastewater Discharges from Septic Tanks}

The use of septic tanks is common throughout the NAWQA study unit. Septic tanks are mostly used for individual households or small commercial establishments (churches, convenience stores, small motels, restaurants, and campgrounds) that are in rural or remote areas, or in urban areas that are not served by a domestic wastewater facility. Water from septic tanks is generally released to the ground through a subsurface drain field (sometimes referred to as an absorption field) after natural biological treatment. In 1990, more than half a million $(550,000)$ septic tanks were in use within the study unit (U.S. Bureau of Census, 1993). Concentrations of septic tanks are common in highly suburbanized counties, where housing growth often occurs in unincorporated areas immediately adjacent to city limit (Marella, 1994). In many cases, these areas are not served by domestic wastewater facilities. Charlotte and Dade Counties have a density of septic tanks greater than 50 per square mile (Marella, 1994). However, the actual density of the septic tanks in areas not served by domestic wastewater facilities 
is greater. For example, about 55 percent of the land in Dade County is in fresh or saltwater marshlands, and is generally uninhabitable (Field and others, 1991). The density of septic tanks in the inhabitable areas would be about 130 tanks per square mile, but it is even greater because most of the inhabited areas are served by a domestic wastewater facility.

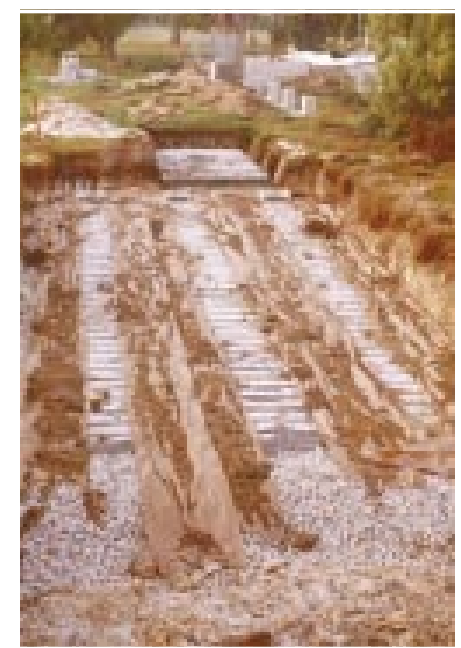

Installation of septic tank and drain field in southern Florida.

Based on an average discharge of $55 \mathrm{gal} / \mathrm{d}$ (gallons per day) per person (Tchobanoglous, 1991) and 2.46 people per household (Smith and Cody, 1992), estimated water released from each septic tank is about $135 \mathrm{gal} / \mathrm{d}$. Discharge from the nearly 550,000 septic tanks in the study unit for 1990 is about $73 \mathrm{Mgal} / \mathrm{d}$. Most of the effluent is released to the subsurface through on-site subsurface drain fields or boreholes that allow the water from the tank to percolate into the ground (usually into the surficial aquifers) and either transpire to the atmosphere through surface vegetation or add to the flow of shallow ground water. Dade County, with nearly 116,300 septic tanks, had estimated releases of nearly $16 \mathrm{Mgal} / \mathrm{d}$ in 1990. The number and density of septic tanks can have important effects on water quality; waste generated from each tank can add high levels of nitrogen (nearly 24 pounds per year) and phosphorus ( 9 pounds per year) to the surficial aquifer and adjacent surface water (Tchobanoglous, 1991).

\section{Agricultural Wastewater Runoff}

One of the most intense areas of agricultural production in the United States is the Everglades Agricultural Area, located south of Lake Okeechobee (fig. 1). Within the EAA, about 400,000 acres of sugarcane (Florida Agricultural Statistics Service, 1991) and nearly 100,000 acres of various vegetable (truck) crops are grown (fig. 4). Surface water is the primary source of water for irrigation. Most of the water originates from Lake Okeechobee and is diverted through canals or ditches, where it is pumped or gravity fed onto fields. Most of the sugarcane is irrigated by subsurface flood systems where the water is used to maintain a high water table in the fields. Excess irrigation water is returned to the canals. An estimated $813 \mathrm{Mgal} / \mathrm{d}$ of surface water was withdrawn or diverted to irrigate sugarcane in 1990 (Marella, 1992), with an unknown percentage of this water returned to the hydrologic system. Vegetable irrigation occurs through either similar subsurface irrigation systems or from traveling guns or portable systems with overhead sprinklers.

Excess water also is returned to surface water sources. Other areas of vegetable production are located near Homestead, in Dade County, and Immokalee, in Collier County (figs. 1 and 4).

Figure 4. Agricultural and urban land use and active landfills in the study unit, 1995. (Modified from South Florida Water Management District and Southwest Florida Water Management District digital data, 1988-90.)

Citrus production is predominantly in the Coastal Flatwoods (Indian River, Martin, and St.Lucie Counties) and on the Lake Wales Ridge (Highlands and Polk Counties). Nearly 641,000 acres of citrus

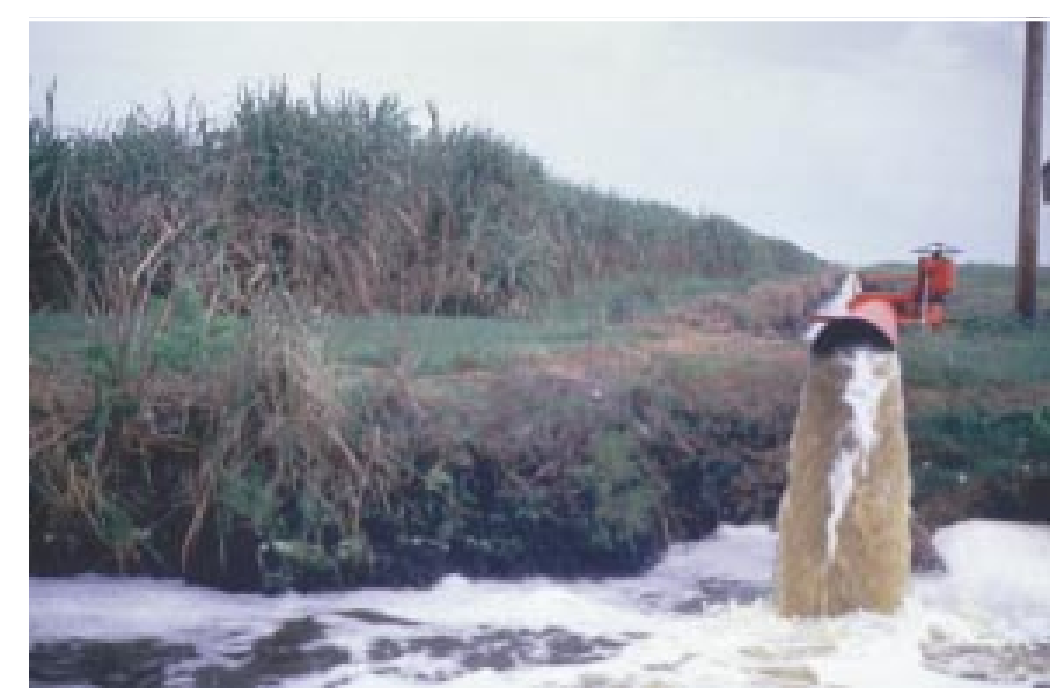

Agricultural discharge in southern Florida. (Photo courtesy of South Florida Water Management District.) 
was in the study unit in 1990 , of which most was irrigated. Citrus acreage increased nearly 118,000 acres from 1980 to 1990 , primarily in Charlotte, Collier, Hendry, and Lee Counties (Florida Agricultural Statistics Service, 1994). Most of the crops in the study unit are cultivated on sandy soils, which have a very low water-holding capacity, or on muck land with a high water-holding capacity. Runoff from these agricultural activities can be significant, especially during rainy seasons when the soil is saturated.

Some of the largest dairy and cattle operations in the United States are in southern Florida. Overall, 70,000 dairy cows and nearly 600,000 beef cows were within the study unit in 1990, and an estimated 250,000 acres of improved pasture was used for grazing in 1992 (U.S. Bureau of Census, 1994). Okeechobee County had more than 45,000 dairy cows and 81,000 beef cows in 1990 (Florida Agricultural Statistics Service, 1992). High nutrient concentrations are attributed to runoff from improved pasture and dairy operations in some areas of southern Florida (Haag and others, 1996).

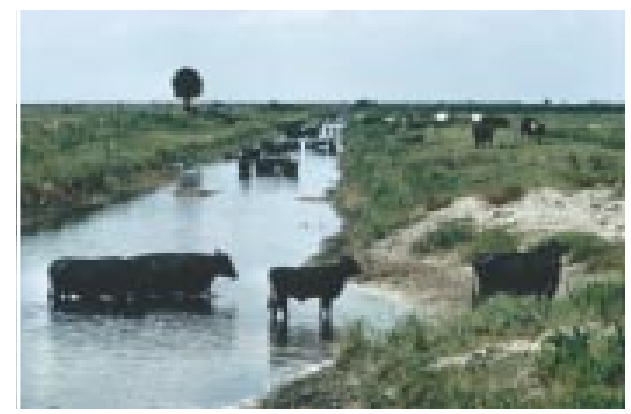

Livestock grazing in southern Florida.

\section{Urban Wastewater Runoff}

Urban development in southern Florida is concentrated near the Atlantic and gulf coasts (fig. 4). The 100-mile stretch of coastline between Miami and West Palm Beach is the largest, most highly urbanized region. In this urbanized region, thousands of acres are covered with impervious parking lots, roads, or buildings that inhibit the percolation of rainfall. The stormwater that collects in retention ponds, canals, or ditches often contains bacteria, viruses, oil and grease, toxic metals, nutrients, and pesticides. These contaminants seep into the ground from ponds, canals, and ditches and adversely affect public water supplies, or they are discharged from canals into lakes and bays, degrading these waters (Klein and others, 1975).

\section{Wastewater Runoff from Landfills}

Landfills are a source of nonpoint pollutants associated with urban areas. Contaminants from landfills leach into the ground and surface waters, adversely affecting water quality. There are approximately 40 active landfills in the study unit that receive an average of 20 or more tons of solid waste per day (fig. 4). Unregulated dumping also occurs in southern Florida.

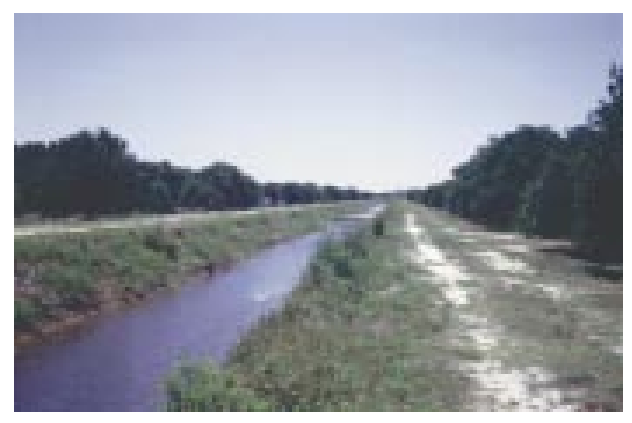

Drainage canal in St. Lucie County.

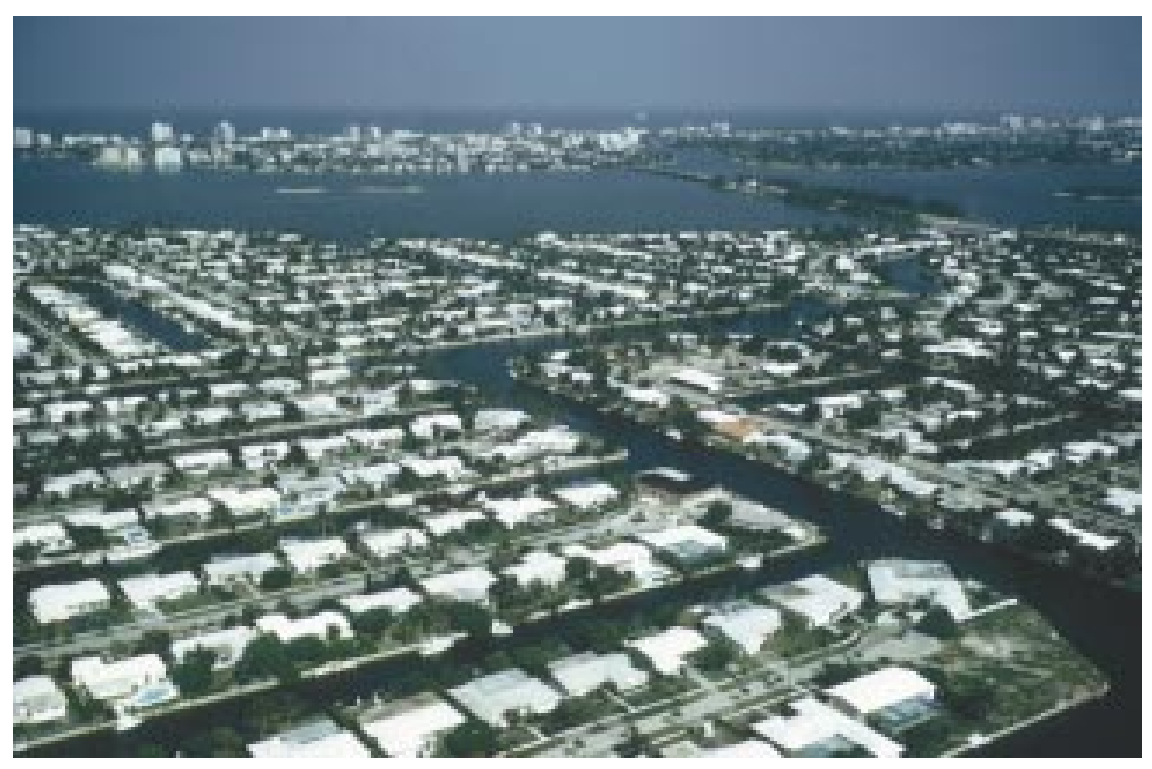

Urban development in southern Florida.

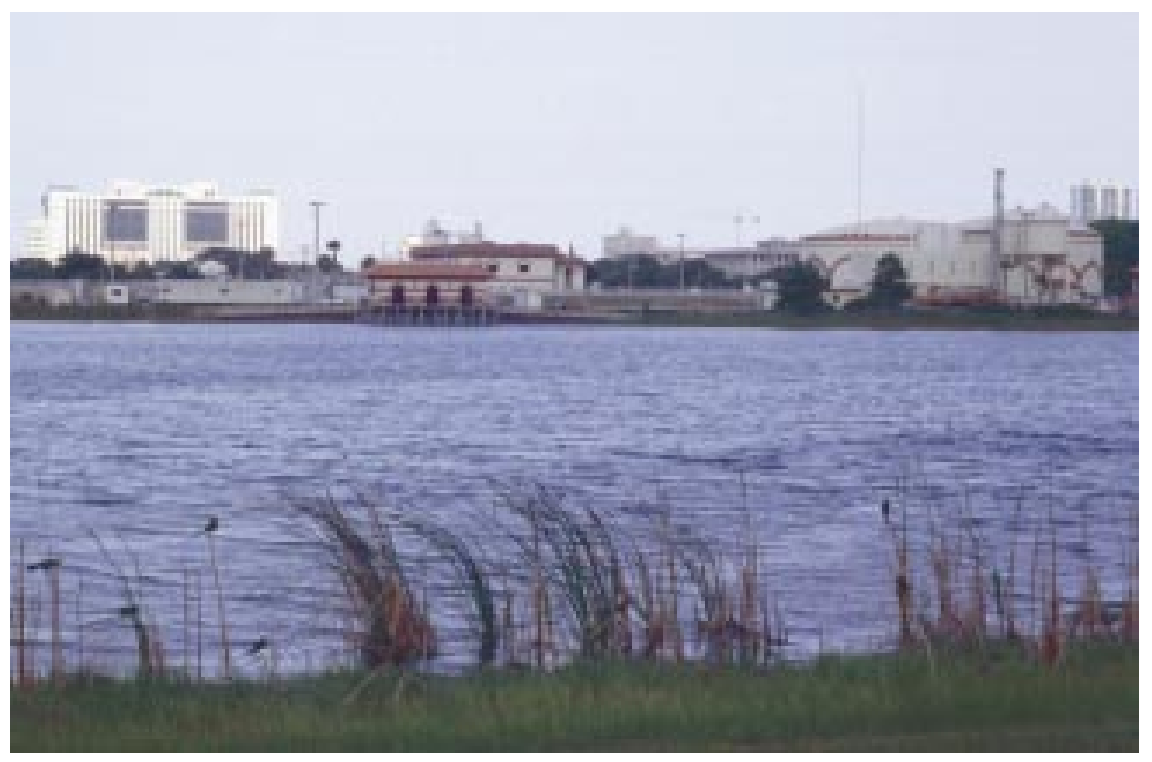

Public supply water source in Palm Beach County. 


\section{REFERENCES}

Field, D.W., Reyer, A.J., Genovese, P.V., and Shearer, B.D., 1991, Coastal wetlands of the United States: Asheville, N.C., U.S. Department of Commerce, National Oceanic and Atmospheric Administration, National Ocean Service, Office of Oceanography and Marine Assessment, Ocean Assessments Division, Strategic Assessment Branch, 59 p.

Flora, M.D., and Rosendahl, P.C., 1982, An analysis of surface water nutrient concentrations in the Shark River Slough, 1972-1980: Homestead, South Florida Research Center Report T-653, 40 p.

Florida Agricultural Statistics Service, 1991, Field crops summary 1990: Orlando, Florida Department of Agriculture and Consumer Services, Agricultural Statistics Service, 19 p.

1992, Livestock, dairy, and poultry summary 1991: Orlando, Florida Department of Agriculture and Consumer Services, Agricultural Statistics Service, $84 \mathrm{p}$.

1994, Commercial citrus inventory 1994: Orlando, Florida Department of Agriculture and Consumer Services, Agricultural Statistics Service, 109 p.
Haag, K.M., Miller, R.L., Bradner, L.A., and McCulloch, D.S., 1996, Water-quality assessment of southern Florida: An overview of available information on surface- and ground-water quality and ecology: U.S. Geological Survey Water-Resources Investigations Report 96-4177, $42 \mathrm{p}$.

Klein, Howard, Armbruster, J.T., McPherson, B.F., and Freiberger, H.J., 1975, Water and the south Florida environment: U.S. Geological Survey Water-Resources Investigations Report 214-75, 165 p.

Marella, R.L., 1992, Water withdrawals, use and trends in Florida, 1990: U.S. Geological Survey Water-Resources Investigations Report 92-4140, 38 p.

1994, Estimated discharge of treated wastewater in Florida, 1990: U.S. Geological Survey Open-File Report 93-364, $53 \mathrm{p}$.

McPherson, B.F., 1994, National waterquality assessment program--Southern Florida: U.S. Geological Survey OpenFile Report 94-57, 2 p.

McPherson, B.F., and Halley, Robert, 1997, The south Florida environment--A region under stress: U.S. Geological Survey Circular 1134, 61 p.
McPherson, B.F., Higer, A.L., Gerould, Sarah, and Kantrowitz, I.H., 1995, South Florida ecosystem program of the U.S. Geological Survey: U.S. Geological Survey Fact Sheet FS-134-95, 4 p.

Shinn, E.A., Reese, R.S., and Reich, C.D., 1994, Fate and pathways of injectionwell effluent in the Florida Keys: U.S Geological Survey Open-File Report 94-276, $121 \mathrm{p}$.

Smith, S.K., and Cody, Scott, 1992, Number of households and average household size in Florida, April 1991: University of Florida, Bureau of Economic and Business Research, v. 25, no. 2, bull. 100, 4 p.

Tchobanoglous, George, 1991, Wastewater engineering, treatment, disposal, and use: Metcalf and Eddy, Inc., 3rd ed., $1334 \mathrm{p}$.

U.S. Bureau of Census, 1993, 1990 Census of housing, detailed housing characteristics; Florida: Washington, D.C., U.S. Department of Commerce, Bureau of the Census, Ch-2-11, 793 p.

1994, 1992 Census of agriculture; Florida state and county data: Washington D.C., U.S. Department of Commerce, Bureau of the Census, geographic area series, v. 1, pt. 9, 439 p.

-by Richard L. Marella

\title{
THE NATIONAL WATER-QUALITY ASSESSMENT (NAWQA) PROGRAM
}

In 1991, the U.S. Geological Survey began the NAWQA Program to describe the status of, and trends in, the quality of the Nation's surface- and ground-water resources, and to identify the natural and human factors that affect the quality of these resources. The NAWQA Program is designed to produce water-quality information that is useful to policymakers and managers at Federal, State, and local levels. The Southern Florida study is one of 60 active or proposed studies nationwide, which represent 60 to 70 percent of the Nation's water use and population served by public water supplies.

\section{U.S. DEPARTMENT OF THE INTERIOR BRUCE BABBITT, Secretary}

\author{
U.S. GEOLOGICAL SURVEY \\ Thomas J. Casadevall, Acting Director
}

For more information, please contact:

Benjamin F. McPherson, Project Chief

Southern Florida Study Unit

U.S. Geological Survey

4710 Eisenhower Blvd., Suite B-5

Tampa, Florida 33634-6381

Telephone: 813-884-9336 FAX - 813-889-9811
For additional copies of this report, please write to:

U.S. Geological Survey

Branch of Information Services

Box 25286

Denver, CO 80225 